\title{
Perchlorate contamination in bottled and other drinking water sources of Kerala, southwest coast of India
}

\author{
M. R. Sijimol ${ }^{1} \cdot{\text { Mahesh } \text { Mohan }^{1} \cdot \text { D. Dineep }}^{1}$ \\ ${ }^{1}$ School of Environmental Sciences, Mahatma Gandhi University, Kottayam, Kerala 686560, India
}

Received: 13 October 2015/Revised: 22 February 2016/ Accepted: 25 February 2016/Published online: 11 March 2016

(C) Joint Center on Global Change and Earth System Science of the University of Maryland and Beijing Normal University and Springer-Verlag Berlin Heidelberg 2016

\begin{abstract}
Perchlorate and chlorate are inevitable components in rocket propellants, fireworks, water treatment, bleaching, textile industry, etc. Knowingly or unknowingly, wide use of these chemicals contaminates drinking water systems. The present study assessed the perchlorate and chlorate contamination of bottled water and other drinking well, tap, bore well, rainwater sources of Kerala and other parts of Peninsular India. Other drinking water samples were collected during the pre-monsoon, monsoon and post-monsoon from the 14 districts of Kerala and were analyzed for perchlorate and chlorate using liquid chromatography-mass spectrometry. Most of the locally available brands of bottled water were found to be contaminated with perchlorate and chlorate. Mean value of perchlorate was found to be $93.19 \mathrm{ppb}$, and that of chlorate was $3692.07 \mathrm{ppb}$, both exceeding the health reference level. The continuous consumption of water with high level of perchlorate content can cause high risk, and the probability of increasing thyroid disorders is high. Perchlorate was detected from well, tap and bore well water samples, and the maximum perchlorate was observed for the premonsoon season, whereas the minimum noticed in the monsoon samples. The high concentration of perchlorate detected in groundwater was mainly due to the industrial units and firework manufacturing and display sites.
\end{abstract}

Keywords Pollution - LC-MS · Bottled water · Chlorate · Thyroid disorders

Mahesh Mohan

mahises@gmail.com; mahises@yahoo.com

\section{Introduction}

Bottled water is one of the fastest-growing industries in India, and the rate is increasing on a more frequent basis, of 40-50\% annually. South India is the biggest consumer of bottled water, representing more than $50 \%$ of the total market in India (The Economic Times 2012). In Kerala, one of the southernmost Indian states, around 0.8 million liters of potable water is sold amongurban communities per day and is increasing every year (IWR 2013). Hence, any contamination of bottled water may affect a large population. The present study aimed to investigate the drinking water contamination with perchlorate and chlorate.

Perchlorate $\left(\mathrm{ClO}_{4}{ }^{-}\right)$and chlorate $\left(\mathrm{ClO}_{3}{ }^{-}\right)$, the inorganic anions of chlorine, are gaining attention because of their immense contamination in drinking water systems. Perchlorate is used as an oxidizer in solid rocket propellants (Tikkanen 2006), fireworks (Sijimol et al. 2014, 2015; Sijimol and Mahesh 2014; Isobe et al. 2012), munitions, signal flares (ITRC 2005; Urbansky 2002), etc. Perchlorate is highly soluble and is persistent in nature (Siglin et al. 2000; Motzer 2001). This results in the contamination of environment, especially aquatic systems, and is very difficult to treat (Logan 1998). Various studies reported perchlorate contamination of surface water, groundwater, tea, soft drinks, beverages, baby formulas, etc. (Snyder et al. 2006; Kannan et al. 2009; Anupama et al. 2012). The awe behind perchlorate contamination is that exceeding the limit of $24.5 \mathrm{ppb}$ perchlorate in drinking water can result in thyroid disorders (Wolff 1998; Anderson et al. 2006; Sijimol et al. 2015).

Chlorate is widely used in matches, laboratories, herbicides, pulp, paper and textile industry, etc. The reduction of perchlorate can also result in chlorate production (USEPA 
2008a). Sodium hypochlorite and chlorine dioxide are used in water treatment, disinfection of microorganisms, pesticide, bleaching, coir and textile industry. About $10 \%$ of the applied chlorine dioxide is converted to chlorate. In hypochlorite solutions, chlorate is generated spontaneously. Like perchlorate, chlorate is also highly soluble (USEPA USEPA 2008a, b; AWWA 2014). It is included in the third Unregulated Contaminant Monitoring Rule (UCMR3) (AWWA 2014). In drinking water, the chronic dietary assessment for chlorate is estimated to be $0.69 \mathrm{mg} / \mathrm{L}$ (USEPA 2008a), whereas the estimated health reference level (HRL) for chlorate is $210 \mu \mathrm{g} / \mathrm{L}$ (AWWA 2014). Moreover, chlorate acts as a thyroid disruptor, resulting in thyroid gland follicular cell hypertrophy though not as strong as perchlorate (USEPA 2008a). It can also impair the oxygen-carrying capacity of blood and thereby ruptures red blood cell membranes in infants and fetuses (NAS 1987).

The major sources of perchlorate in Kerala are Ammonium Perchlorate Experimental Plant (APEP), Thumba Equatorial Rocket Launching Station (TERLS), firework manufacturing sites and innumerable firework displays (Sijimol and Mahesh 2014). Major industrial source of chlorate is Travancore Cochin Chemicals Limited where sodium chlorate is manufactured and used for ammonium perchlorate production at APEP (The Hindu 2013). The 800 tonnes of ammonium perchlorate produced by APEP is consumed by TERLS as rocket propellant. Sodium hypochlorite used in drinking water treatment plants can also act as a source of chlorate.

The literature indicates that a very few works have been carried out in India, to estimate the perchlorate contamination in drinking water (Kannan et al. 2009; Isobe et al. 2012; Anupama et al. 2012, 2015). Widespread occurrence of perchlorate in public drinking, open well and surface water sources was reported along the southwest coast of Kerala (Anupama et al. 2012). Hence, the present study aimed to understand the perchlorate and chlorate contamination of well water, bore well water, tap water, bottled water and rainwater in Kerala.

\section{Materials and methods}

\subsection{Study area and sample collection}

Kerala is situated along the southwest coast of India. Drinking water samples were collected from water supplies of selected towns from all the fourteen districts of Kerala. The 14 districts were classified into 3 regions-southern region (Trivandrum, Kollam, Pathanamthitta, Alappuzha), central region (Kottayam, Idukki, Thrissur, Ernakulam, Palakkad) and northern region (Kozhikode, Malappuram, Kannur, Kasaragod, Wayanad) (Fig. 1).
Drinking water samples (well, bore well and tap) were collected during April-May 2014 (before onset of monsoon); August-September 2014 (during monsoon) and December 2014-January, 2015 (after monsoon). Water samples were filtered using $0.2-\mu$ nylon membrane filter paper and stored below $4{ }^{\circ} \mathrm{C}$ until the analysis performed.

Different brands (local and international) $(n=31)$ of bottled water were collected from different districts of Kerala. The number of samples from each district is given in Table 1. A few bottled water samples $(n=5)$ were randomly collected from other states also (Maharashtra, Andhra Pradesh, Tamil Nadu and Karnataka). The samples were filtered using $0.2-\mu$ filter paper and stored in sterile polypropylene bottles, under $4{ }^{\circ} \mathrm{C}$ for the analysis.

Rainwater samples $(n=15)$ were collected during the summer season from selected towns of Kerala. Samples were then filtered and analyzed for perchlorate and chlorate.

\subsection{Sample analysis}

Liquid chromatography-mass spectrometry (LC-MS) (Shimadzu LCMS-2020) with Dionex AS $21(250 \mathrm{~mm} \times 4 \mathrm{~mm}$ diameter) column was used for perchlorate and chlorate analysis. Selective ion monitoring (SIM) technique was used for the detection. For perchlorate, $\mathrm{m} / \mathrm{z} 101$ (the isotopic mass of perchlorate $\mathrm{m} / \mathrm{z}$ 99) was used for quantification, while hydrogen sulfate, $\mathrm{H}^{34} \mathrm{SO}_{4}$, the common anion in water, also had $m / z$ 99. For the confirmation of a peak as of perchlorate, the ratio ${ }^{35} \mathrm{Cl}:{ }^{37} \mathrm{Cl}(\mathrm{m} / \mathrm{z}, 99: \mathrm{m} / \mathrm{z}$ 101) was calculated and the ratio $3 \pm 25 \%$ was accepted. The method detection limit (MDL) was $2 \mathrm{ppb}$ and the limit of quantification (LoQ) was $6 \mathrm{ppb}$ for perchlorate, whereas those for chlorate were 4 and $10 \mathrm{ppb}$, respectively.

\subsection{Risk assessment calculation}

The established reference dose of perchlorate per kilogram body weight per day is $0.7 \mu \mathrm{g} / \mathrm{kg} / \mathrm{bw} / \mathrm{day}$ (USEPA 2008b). Risk assessment of perchlorate was calculated separately for entire Kerala (different seasons), regionwise (different seasons) and based on the type of drinking water.

Intake $(\mu \mathrm{g} / \mathrm{kg}$ body $\mathrm{wt} /$ day $)=\mathrm{CW} \times \mathrm{IR} \times \mathrm{ED} / \mathrm{BW}$,

where $\mathrm{CW}$ - chemical concentration in water $(\mu \mathrm{g} / \mathrm{L})$, IRintake rate (L/day), ED-exposure duration (day), BWbody weight (kg) (Wu et al. 2010, 2011).

\section{Results and discussion}

\subsection{Bottled water}

Of the 36 brands of bottled water analyzed, 20 samples showed perchlorate (Fig. 2) and 32 samples showed 


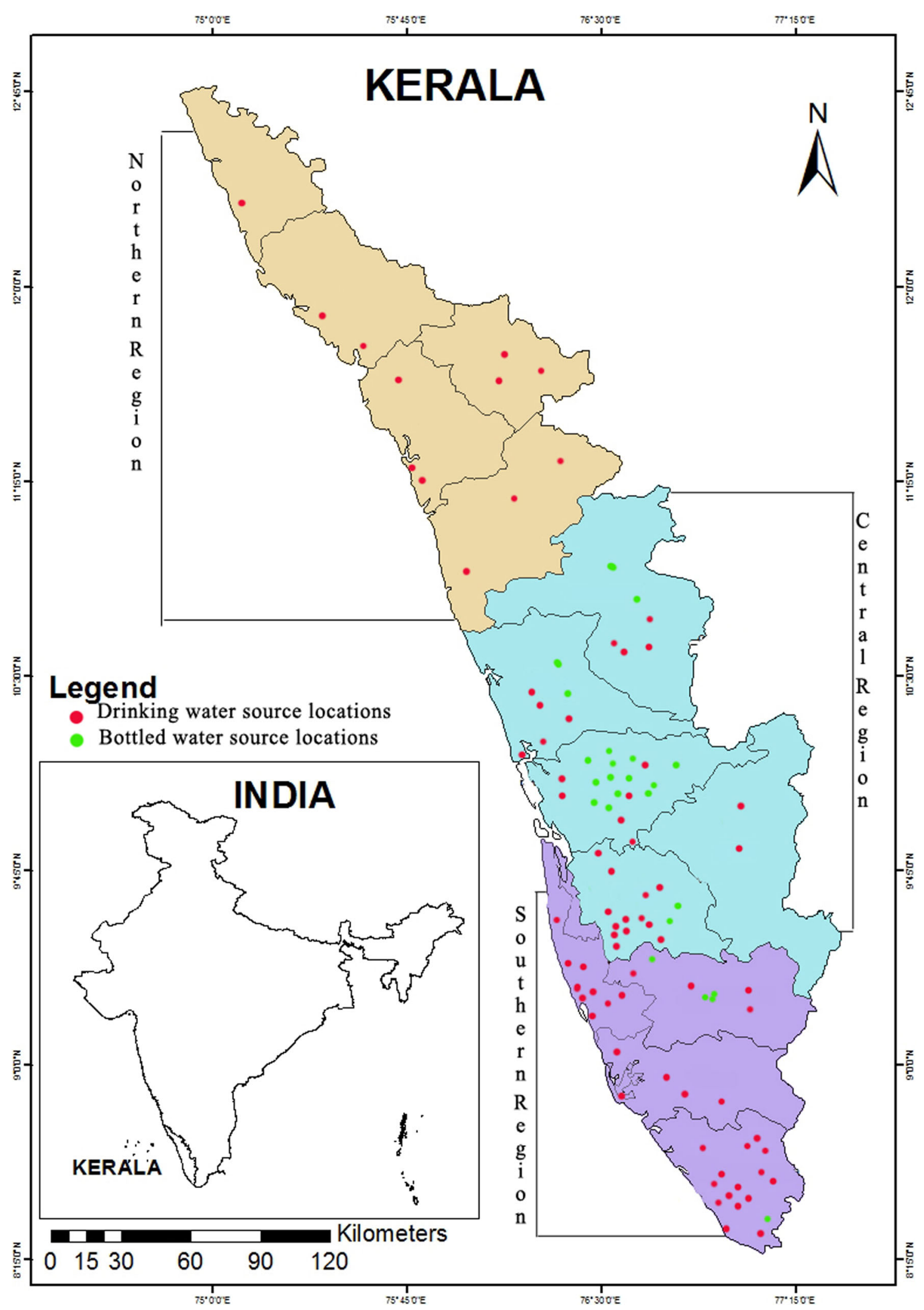

Fig. 1 Map showing bottled water and other drinking water source locations 
Table 1 Mean perchlorate and chlorate concentration in different bottled water samples

\begin{tabular}{|c|c|c|c|c|c|}
\hline $\begin{array}{l}\text { Sample } \\
\text { no. }\end{array}$ & Sample ID & $\begin{array}{l}\text { No. of samples } \\
\text { analyzed }\end{array}$ & Manufacturing place & Perchlorate (ppb) & Chlorate (ppb) \\
\hline 1 & BW1 & 8 & Ernakulam & 1067.89 & 7328.89 \\
\hline 2 & BW2 & 6 & Pathanamthitta & 162.74 & 1821.96 \\
\hline 3 & BW3 & 5 & Palakkad & 19.77 & 101.2 \\
\hline 4 & BW4 & 1 & Ernakulam & 0 & 1304.64 \\
\hline 5 & BW5 & 6 & Bangalore, Karnataka* & 0 & 399.68 \\
\hline 6 & BW6 & 1 & Pathanamthitta & 90.34 & 3014.24 \\
\hline 7 & BW7 & 1 & Thrissur & 42.65 & 488.32 \\
\hline 8 & BW8 & 1 & Thrissur & 94.02 & $40,705.84$ \\
\hline 9 & BW9 & 1 & Thiruvananthapuram & 126.17 & $20,500.16$ \\
\hline 10 & BW10 & 1 & Ernakulam & 0 & 388.64 \\
\hline 11 & BW11 & 1 & Ernakulam & 0 & 1942.56 \\
\hline 12 & BW12 & 1 & Kanchipuram, Tamil Nadu* & 0 & 75.92 \\
\hline 13 & BW13 & 2 & Pathanamthitta & 0 & 120.8 \\
\hline 14 & BW14 & 1 & Pathanamthitta & 0 & $10,912.24$ \\
\hline 15 & BW15 & 1 & Hyderabad* & 0 & 149.28 \\
\hline 16 & BW16 & 2 & Ernakulam & 17.14 & 487.36 \\
\hline 17 & BW17 & 2 & Pathanamthitta & 10.26 & 1007.76 \\
\hline 18 & BW18 & 3 & Ernakulam & 44.63 & 427.92 \\
\hline 19 & BW19 & 2 & Thrissur & 0 & 5644.4 \\
\hline 20 & BW20 & 2 & Ernakulam & 15.97 & 1090.08 \\
\hline 21 & BW21 & 1 & Thiruvananthapuram & 0 & 0 \\
\hline 22 & BW22 & 1 & Palakkad & 0 & 345.04 \\
\hline 23 & BW23 & 1 & Mumbai* & 0 & 0 \\
\hline 24 & BW24 & 1 & Ernakulam & 40.38 & 462.96 \\
\hline 25 & BW25 & 1 & Andheri, Mumbai* & 24.12 & 108.48 \\
\hline 26 & BW26 & 1 & Ernakulam & 0 & 1435.12 \\
\hline 27 & BW27 & 1 & Ernakulam & 19.05 & 3651.68 \\
\hline 28 & BW28 & 2 & Ernakulam & 16.05 & 2051.6 \\
\hline 29 & BW29 & 2 & Ernakulam & 13.12 & 7129.84 \\
\hline 30 & BW30 & 1 & Ernakulam & 9.51 & 521.92 \\
\hline 31 & BW31 & 1 & Ernakulam & 9.78 & 0 \\
\hline 32 & BW32 & 1 & Kottayam & 0 & 434.4 \\
\hline 33 & BW33 & 1 & Ernakulam & 32.2 & 0 \\
\hline 34 & BW34 & 2 & Kottayam & 0 & 1711.48 \\
\hline 35 & BW35 & 1 & Ernakulam & 7.91 & 430.88 \\
\hline \multirow[t]{2}{*}{36} & BW36 & 2 & Ernakulam & 0 & 1950.88 \\
\hline & & & Mean & 84.71 & 3281.84 \\
\hline
\end{tabular}

* Samples manufactured outside Kerala

chlorate contamination (Table 1). Mean perchlorate content in bottled water was $84.71 \mathrm{ppb}$, whereas for chlorate was $3281.84 \mathrm{ppb}$. The observed perchlorate content in 9 samples was higher than the health reference level for chlorate content in drinking water given by USEPA (24.5 ppb). Twenty-one samples exceeded the health reference level for chlorate. Samples from Kottayam district, which is free from industrial sources, have perchlorate within below detectable limit (BDL $<6 \mathrm{ppb})$. More than $70 \%$ of the samples from Ernakulam district showed perchlorate contamination. Perchlorate contamination was already reported from groundwater and surface water from Ernakulam district, near to APEP (Anupama et al. 2012). The source of surface water for bottled water manufacturing in Ernakulam district is Periyar River, which is the main reason behind the widespread perchlorate 


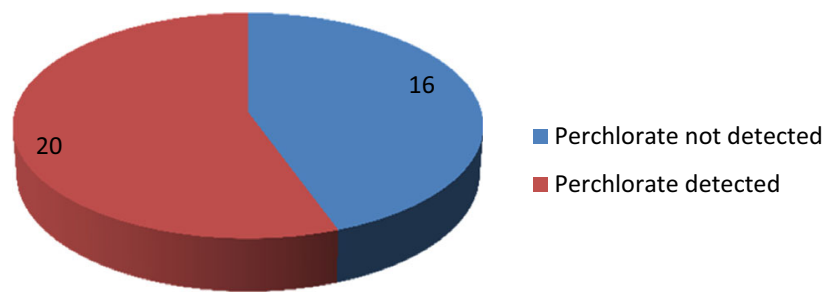

Fig. 2 Graph showing perchlorate detected and perchlorate undetected samples

contamination of bottled water from the region. The sample contaminated with perchlorate obtained from Trivandrum district is manufactured from Thumba nearby TERLS. Veli Lake is the source of water, which is contaminated with perchlorate (Anupama et al. 2012). The contamination at other districts can be owed to the firework manufacturing units as most of the districts in Kerala have licensed and unlicensed small-scale and large-scale units. It is interesting to note that out of 5 outside state samples analyzed, 4 samples are having perchlorate in BDL and the only one (from Mumbai) is having perchlorate (12.06 ppb) within the safe limit (Fig. 3). This shows either uncontrolled use and mishandling of the chemical or lacking of advanced systems for perchlorate removal in the study area. Perchlorate contamination of bottled water is thus found to be dependent on the source contamination.

Chlorate contamination is noticed in almost all samples, irrespective of their source of manufacturing. Both within state and outside state samples were contaminated with chlorate and found to be source independent. This may be owed to the disinfection processes using hypochlorites. In Kerala, sodium hypochlorite as such is used in treating large quantities of drinking water supplies (The Hindu 2008).

Almost all the samples underwent treatment processes such as reverse osmosis, microfiltration, UV irradiation before packaging, and the results suggest that those processes are inefficient in removing perchlorate and chlorate. Various studies reported the possibility of removing perchlorate using technologies such as physical separation (precipitation, anion exchange or membrane filtration, reverse osmosis and electrodialysis), chemical and electrochemical reduction, and biological or biochemical reduction (Urbansky 1998; Srinivasan and Viraraghavan 2009), but it is found that typical water treatment technologies cannot remove perchlorate (Logan 1998).

Various studies reported perchlorate and chlorate contamination of bottled water in different countries (Table 2). Global perchlorate values ranged from $<0.02$ to $2.01 \mathrm{ppb}$ and chlorate values ranged from 5.8 to $343 \mathrm{ppb}$, with China being the topmost in both perchlorate and chlorate contamination. Perchlorate detected from bottled water in Kerala was found to be far above the values reported from other countries. But the measured perchlorate value from bottled water was comparable to the tap water (38.4 ppb), groundwater (34.1 ppb) and surface water (17 ppb) values in Kerala (Anupama et al. 2012).

\subsection{Other drinking water sources}

The analytical results of drinking water samples such as well, bore well and tap water are given according to regionwise and drinking water type (Table 4). Perchlorate content for the drinking water samples ranged from
Fig. 3 Graph comparing the mean perchlorate of different sources $[K$-Kerala manufactured samples, $O$ outside state manufactured samples]

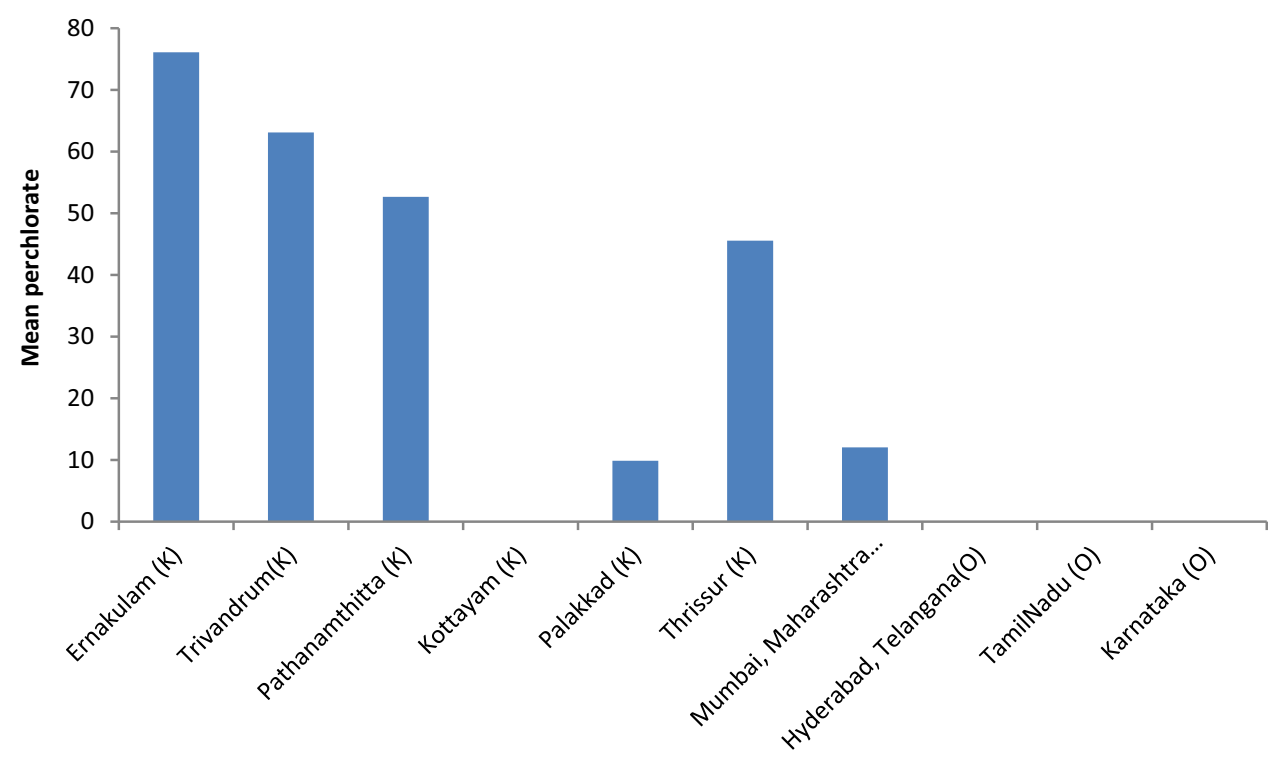

Source of manufacturing 
Table 2 Comparison of perchlorate in bottled water with other reported values

\begin{tabular}{llll}
\hline Country & Perchlorate $(\mathrm{ppb})$ & Chlorate $(\mathrm{ppb})$ & References \\
\hline US & 0.405 & 5.8 & Snyder et al. (2005) \\
Japan & 0.53 & 14 & Asami et al. (2009) \\
China & 2.013 & 343 & Shi et al. (2007), Wu et al. (2010) \\
South Korea & 0.07 & - & Her et al. (2011) \\
Italy & 0.075 & - & Iannece et al. (2013) \\
India (7 states excluding Kerala) & $<0.02$ (quantitation limit) & - & Kannan et al. (2009) \\
Canada & - & 6.9 & Dabeka et al. (2002) \\
\hline
\end{tabular}

Table 3 Mean perchlorate (ppb) in well water samples from various districts of Kerala during different times in a year

\begin{tabular}{|c|c|c|c|c|c|c|c|}
\hline \multirow[t]{2}{*}{ S1. no. } & \multirow[t]{2}{*}{ District } & \multicolumn{2}{|c|}{ April-May 2014} & \multicolumn{2}{|c|}{ August-September 2014} & \multicolumn{2}{|c|}{ December 2014-January 2015} \\
\hline & & $\mathrm{ClO}_{4}^{-}(n)$ & $\mathrm{ClO}_{3}{ }^{-}$ & $\mathrm{ClO}_{4}^{-}(n)$ & $\mathrm{ClO}_{3}^{-}$ & $\mathrm{ClO}_{4}^{-}(n)$ & $\mathrm{ClO}_{3}^{-}$ \\
\hline 1 & Thiruvananthapuram & $71.86 *(12)$ & 365.05 & $0(13)$ & 0 & $1.98(13)$ & 0 \\
\hline 2 & Kollam & $14.45(5)$ & 99.07 & $0(5)$ & 0 & $27.45^{*}(5)$ & 33.71 \\
\hline 3 & Pathanamthitta & $178.93 *(5)$ & 17.184 & $0(5)$ & 0 & $0(5)$ & 0 \\
\hline 4 & Alappuzha & $1172.37 *(8)$ & 289.95 & $0(9)$ & 0 & $27.34 *(8)$ & 58.84 \\
\hline 5 & Kottayam & $30.69 *(12)$ & 201.39 & $0.47(13)$ & 0 & $19.19(13)$ & 96.53 \\
\hline 6 & Idukki & $102.19 *(20)$ & 0 & $5.82(3)$ & 0 & $19.3(2)$ & 0 \\
\hline 7 & Ernakulam & $40.48 *(8)$ & 166.05 & $0(8)$ & 0 & $21.84(8)$ & 0 \\
\hline 8 & Thrissur & $29.37 *(6)$ & 15.07 & $0(6)$ & 0 & $0(6)$ & 0 \\
\hline 9 & Palakkad & $60.09 *(6)$ & 259.16 & $0(4)$ & 0 & $0(4)$ & 0 \\
\hline 10 & Malappuram & $23.92(3)$ & 0 & $0(4)$ & 0 & $5.68(5)$ & 9.50 \\
\hline 11 & Kozhikode & $39.09 *(2)$ & 0 & $0(2)$ & 0 & $64.68 *(3)$ & 28.08 \\
\hline 12 & Wayanad & $121.04 *(2)$ & 0 & $0(3)$ & 0 & $0(2)$ & 0 \\
\hline 13 & Kannur & $7.97(1)$ & 0 & $0(1)$ & 0 & $34.34 *(2)$ & 0 \\
\hline \multirow[t]{2}{*}{14} & Kasaragod & $254.14 *(1)$ & 154.56 & $0(1)$ & 0 & $95.72 *(1)$ & 0 \\
\hline & Total mean & $153.33 *$ & 111.96 & 0.45 & 0 & 22.68 & 16.19 \\
\hline
\end{tabular}

(n) - number of samples

Number of samples analyzed are given in italics

* Concentration exceeding the permissible level of $24.5 \mathrm{ppb}$

$0.71 \mathrm{ppb}$ (monsoon) to $78.45 \mathrm{ppb}$ (pre-monsoon) with a mean value of $33.48 \mathrm{ppb}$. Maximum perchlorate was detected in pre-monsoon samples. Chlorate value ranged from $4.59 \mathrm{ppb}$ (monsoon) to $247.19 \mathrm{ppb}$ (pre-monsoon) with an average of $58.04 \mathrm{ppb}$.

The results are also discussed based on regionwise such as southern, central and northern parts of Kerala (Table 4). Southern part of Kerala showed a mean perchlorate content of $40.69 \mathrm{ppb}$ and chlorate content of $211.07 \mathrm{ppb}$. High mean perchlorate content was observed for northern region (42.36 ppb), whereas minimum was noticed for central region (18.5 ppb). Chlorate was maximum at southern part and minimum at northern part (12.10 ppb).

The results were also compared based on the different types of drinking water such as well, bore well and tap water (Table 4). Well water showed high mean perchlorate and chlorate contents during pre-monsoon (153.33 ppb), whereas minimum was observed during monsoon (Table 3). The mean perchlorate and chlorate contents in well water samples from the entire Kerala were 58.82 and $42.72 \mathrm{ppb}$, respectively, and those varied from southern region (124.53 and $71.98 \mathrm{ppb}$ ) to central region (21.96 and $49.21 \mathrm{ppb})$ and northern region (43.10 and $12.81 \mathrm{ppb}$ ) (Table 4).

In the case of bore well water, average perchlorate and chlorate contents were 6.22 and $29.30 \mathrm{ppb}$, respectively, in Kerala. Perchlorate content was maximum at northern region $(10.44 \mathrm{ppb})$, whereas maximum chlorate content was observed at southern region. Minimum mean perchlorate content was noticed at central region (1.74 ppb), and chlorate was in BDL at northern region. Tap water was also found to be contaminated with perchlorate and chlorate (Table 4). The mean concentration of perchlorate and chlorate in tap water in Kerala was 3.54 and 104.84 ppb, respectively. Central region had high mean perchlorate 
Table 4 Mean perchlorate and chlorate in other drinking water samples (ppb)

\begin{tabular}{|c|c|c|c|c|c|c|c|c|}
\hline & \multirow{2}{*}{\multicolumn{2}{|c|}{$\begin{array}{l}\text { Other drinking } \\
\text { water samples }\end{array}$}} & \multicolumn{6}{|c|}{ Water type } \\
\hline & & & \multicolumn{2}{|c|}{ Well water } & \multicolumn{2}{|c|}{ Bore well water } & \multicolumn{2}{|c|}{ Tap water } \\
\hline & $\mathrm{ClO}_{4}^{-}$ & $\mathrm{ClO}_{3}{ }^{-}$ & $\mathrm{ClO}_{4}^{-}$ & $\mathrm{ClO}_{3}{ }^{-}$ & $\mathrm{ClO}_{4}^{-}$ & $\mathrm{ClO}_{3}^{-}$ & $\mathrm{ClO}_{4}^{-}$ & $\mathrm{ClO}_{3}^{-}$ \\
\hline Kerala & 33.48 & 58.04 & 58.82 & 42.72 & 6.22 & 29.30 & 3.54 & 104.84 \\
\hline Southern region & 40.69 & 211.07 & 124.53 & 71.98 & 6.56 & 74.54 & 3.19 & 231.08 \\
\hline Central region & 18.85 & 67.99 & 21.96 & 49.21 & 1.74 & 22.44 & 7.36 & 108.68 \\
\hline Northern region & 42.36 & 12.10 & 43.10 & 12.81 & 10.42 & 0 & 0 & 0 \\
\hline
\end{tabular}

\begin{tabular}{llcc}
\hline Water & Category & $\mathrm{ClO}_{4}^{-}(\mathrm{ppb})$ & $\begin{array}{l}\text { Intake } \\
(\mu \mathrm{g} / \mathrm{kg} / \mathrm{day})\end{array}$ \\
\hline Other water sources & Kerala & 33.48 & $1.12^{*}$ \\
& Southern region & 40.69 & $1.36^{*}$ \\
& Central region & 18.85 & 0.63 \\
& Northern region & 42.36 & $1.41^{*}$ \\
Well & Kerala & 58.82 & $1.96^{*}$ \\
& Southern region & 124.53 & $4.15^{*}$ \\
& Central region & 21.96 & $0.73^{*}$ \\
Tap & Northern region & 43.1 & $1.44^{*}$ \\
& Kerala & 3.54 & 0.12 \\
& Southern region & 3.19 & 0.11 \\
& Central region & 7.36 & 0.25 \\
Bore well & Northern region & 0 & 0 \\
& Kerala & 6.22 & 0.21 \\
& Southern region & 6.56 & 0.22 \\
& Central region & 1.74 & 0.06 \\
& Northern region & 10.42 & 0.35 \\
\hline
\end{tabular}

* Higher than the permissible intake of $0.7 \mu \mathrm{g} / \mathrm{kg} /$ day (USEPA 2008b)
Table 5 Average perchlorate intakes from well, bore well and tap water in different regions content $(7.366 \mathrm{ppb})$ than the other regions, whereas chlorate was high at southern region (231.08 ppb). Perchlorate and chlorate contents in tap water in the northern region were found to be below the detectable limit.

Out of the 15 rainwater samples analyzed, two samples showed the presence of perchlorate and the values ranged from 6.9 to $12.8 \mathrm{ppb}$, while chlorate was not detected in any of the samples. This might be the effect of firework residuals in the air as the samples were collected during summer, the festival time of Kerala when lots of fireworks occur. Earlier studies also showed the presence of perchlorate in rainwater samples of other parts of India $(<0.02 \mathrm{ppb})$ (Kannan et al. 2009), but it was very low when compared with the mean perchlorate in rainwater samples of the present study ( $9.85 \mathrm{ppb})$.

\subsection{Risk assessment}

The recommended health protective dose of perchlorate is $0.0007 \mathrm{mg} / \mathrm{kg}$ body weight/day $(0.7 \mu \mathrm{g} / \mathrm{kg}$ body weight/day) (USEPA 2008b; Groef et al. 2006), which is equivalent to $24.5 \mathrm{ppb}$ perchlorate in drinking water. Average daily perchlorate intake was calculated with respect to regionwise and sample type (Table 5). The calculation considered the intake of drinking water as $2 \mathrm{~L}$ and the average body weight of a healthy adult in Kerala as $60 \mathrm{~kg}$ (Shome et al. 2014). The whole water samples showed a higher risk value $(1.12 \mu \mathrm{g} / \mathrm{kg}$ body weight/day) than the safe limit of $0.7 \mu \mathrm{g} / \mathrm{kg}$ body weight/day. High risk was observed for northern region followed by southern region, whereas central region is under safe limit. Tap water and bore well water were also within the safe limit, but the well water samples $(0.73-4.15 \mu \mathrm{g})$ were higher than the safe limit.

Widespread drinking water contamination in Kerala can be accounted for the use of rocket propellants and fireworks manufacturing. Further research is needed to confirm the role of natural perchlorate formation, as a source in the study area (Rajagopalan et al. 2006; Anupama et al. 2012). 


\section{Conclusion}

The present study noticed a high perchlorate contamination of the drinking water sources such as bottled water and other drinking water, which urges immediate action in this regard. Both perchlorate and chlorate showed values above the reference levels. This shows that water is not properly treated or the treatment is ineffective before they are packed and sold. The results clearly indicated the role of perchlorate manufacturing industries and firework manufacturing and displaying processes in contamination of water resources. The perchlorate and chlorate in exceeding amounts than the health reference levels point to a probability of increasing thyroid disorders in the future, if chronic exposure to such levels occurred.

Acknowledgments The authors acknowledge the financial support from Department of Environment and Climate Change, Government of Kerala, through a major project. The financial support from DSTFIST and DST-PURSE, Government of India, for developing instrumental facility is gratefully acknowledged. The first author also acknowledges the Junior Research Fellowship from UGC, Government of India.

\section{References}

Anderson CB, Blount BC, LaKind JS, Naiman DQ, Wilbur SB, Tan S (2006) Estimates of exposures to perchlorate from consumption of human milk, dairy milk, and water and comparison to current reference dose. J Toxicol Environ Health Part A 69:319-330. doi:10.1080/15287390500323420

Anupama VN, Kannan K, Prajeesh PV, Rugmini S, Krishnakumar B (2012) Perchlorate, chlorate and bromate in water samples from the South-West Coast of India. Water Sci Technol Water Supply 12(5):595-603

Anupama VN, Prajeesh GP, Krishnakumar B (2015) Surveillance of perchlorate in ground water, surface water and bottled water in Kerala, India. J Environ Health Sci Eng 13:56. doi:10.1186/ s40201-015-0213-z

Asami M, Kosaka K, Yoshida N (2009) Occurrence of chlorate and perchlorate in bottled beverages in Japan. J Health Sci 55:549-553

AWWA, American Water Works Association (2014) The potential regulatory implications of chlorate. www.awwa.org/portals/0/ files/...2014AWWAChlorateBriefingPaper.pdf

Dabeka RW, Conacher HBS, Lawrence JF, Newsome WH, McKenzie A, Wagner HP, Chadha RKH, Pepper K (2002) Survey of bottled drinking waters sold in Canada for chlorate, bromide, bromate, lead, cadmium and other trace elements. Food Addit Contam 19(8):721-732. doi:10.1080/02652030210140905

Groef BD, Decallonne BR, Geyton SV, Darras VM, Bouillon R (2006) Perchlorate versus other environmental sodium/iodide symporter inhibitors: potential thyroid related health effects. Eur J Endocrinol 155:17-25

Her N, Jeong H, Kim J, Yoon Y (2011) Occurrence of perchlorate in drinking water and seawater in South Korea. Arch Environ Contam Toxicol 61:166-172

Iannece P, Motta O, Tedesco R, Carotenuto M, Proto A (2013) Determination of perchlorate in bottled water from Italy. Water 5:767-779
Isobe T, Ogawa PS, Sugimoto R, Ramu K, Sudaryanto A, Malavannan G, Devanathan G, Ramaswamy BR, Munuswamy N, Ganesh DS, Sivakumar J, Sethuraman A, Parthasarathy V, Subramanian A, Field J, Tanabe S (2012) Perchlorate contamination of groundwater from fireworks manufacturing area in South India. Environ Monit Assess 185:5627-5637. doi:10.1007/s10661-0122972-7

ITRC (Interstate Technology and Regulatory Council) (2005) Perchlorate: overview of issues, status and remedial options. PERCHLORATE-1. Interstate Technology and Regulatory Council, Perchlorate Team, Washington, DC. http://www. itrcweb.org

IWR, India Water Review (2013) Kerala Govt. to provide bottled water at lost cost. www.indiawaterreview.in/story/News/keralagovt-to-provide-bottled-water-at-lost0cost/1369/1\#.VD-bGfz6-g

Kannan K, Praamsma ML, Oldi JF, Kunisue T, Sinha RK (2009) Occurrence of perchlorate in drinking water, groundwater, surface water and human saliva from India. Chemosphere $76: 22-26$

Logan BE (1998) A review of chlorate- and perchlorate-respiring microorganisms. Bioremediat J 2(2):69-79

Motzer WE (2001) Perchlorate: problems, detection and solutions. Environ Forensics 2:301-311. doi:10.1006/enfo.2001.0059

NAS (1987) Drinking water and health, vol 4. National Academy of Sciences, National Academy Press, Washington, DC

Rajagopalan S, Anderson TA, Fahlquist L, Rainwater KA, Ridley M, Jackson WA (2006) Widespread presence of naturally occurring perchlorate in high plains of Texas and New Mexico. Environ Sci Technol 40:3156-3162

Shi Y, Zhang P, Wang Y, Shi J, Cai Y, Mou S, Jiang G (2007) Perchlorate in sewage sludge, rice, bottled water and milk collected from different areas in China. Environ Int 33:955-962

Shome S, Roy P, Pal M, Bharati P (2014) Variation of adult heights and weights in india: state \& zonewise analysis. Hum Biol Rev 3(3):242-257

Siglin JC, Mattie DR, Dodd DE, Hilderbrandt PK, Baker WH (2000) A 90-day drinking water toxicity study in rats of the environmental contaminant ammonium perchlorate. Toxicol Sci 57:61-74

Sijimol MR, Mahesh M (2014) Environmental impacts of perchlorate with special reference to fireworks-a review. Environ Monit Assess 186:7203-7210. doi:10.1007/s10661-014-3921-4

Sijimol MR, Renju K, Mahesh M (2014) Fireworks: a disaster and an environment pollution source. In: Pradeepkumar AP, Behr FJ, Illiyas FT, Shaji E (eds) Proceedings of 2nd disaster risk and vulnerability conference, pp 242-246. ISBN 9788192344928

Sijimol MR, Jyothi S, Pradeepkumar AP, Shylesh CMS, Mahesh M (2015) A review on fate, toxicity and remediation of perchlorate. Environ Forensics 16(2):125-134

Snyder SA, Vanderford BJ, Rexing DJ (2005) Trace analysis of bromate, chlorate, iodate and perchlorate in natural and bottled waters. Environ Sci Technol 39:4586-4593

Snyder SA, Pleus RC, Vanderford BJ, Holady JC (2006) Perchlorate and chlorate in dietary supplements and flavor enhancing ingredients. Anal Chim Acta 567:26-32

Srinivasan A, Viraraghavan T (2009) Perchlorate: health effects and technologies for its removal from water resources. Int J Environ Res Public Health 6:1418-1442. doi:10.3390/ijerph6041418

The Economic Times (2012) India behind world average in bottled water consumption. http://www.articles.economictimes.india times.com/keyword/bottled-water/featured/2

The Hindu (2008) Piped drinking water safe says Kerala Water Authority. www.thehindu.com/todays-paper/tp-national/tp-ker ala/piped-drinking-water-safe-says-kerala-water-authority/arti cle127609.ece 
The Hindu (2013) TCC to produce hi-tech fuel for space agency. www.thehindu.com/todays-paper/tp-national/tp-kerala/tcc-to-pro duce-hitech-fuel-for-space-agency/article4954835.ece

Tikkanen MW (2006) Development of a drinking water regulation for perchlorate in California. Anal Chim Acta 567:20-25

Urbansky ET (1998) Perchlorate chemistry: implications for analysis and remediation. CRC Press LLC, Boca Raton, pp 81-95

Urbansky ET (2002) Perchlorate as an environmental contaminant. Environ Sci Pollut Res 9(3):187-192

USEPA (2008a) Inorganic chlorates facts. EPA 738-F-08-001. www. epa.gov/oppsrrd1/REDs/factsheets/inorganicchlorates-fs.pdf

USEPA (2008b) Interim drinking water health advisory for perchlorate. http://www.epa.gov/safewater/contaminants/unregulated/ perchlorate.html
Wolff J (1998) Perchlorate and the thyroid gland. Pharmacol Rev 50(1):89-105

Wu Q, Zhang T, Sun H, Kannan K (2010) Perchlorate in tap water, groundwater, surface waters and bottled water from China and its association with other inorganic anions and with disinfection byproducts. Arch Environ Contam Toxicol 58:543-550

Wu Q, Oldi FJ, Kannan K (2011) Fate of perchlorate in a man-made reflecting pond following a fireworks display in Albany, New York, USA. Environ Toxicol Chem 30:2449-2455 